\title{
KEEFEKTIFAN PENDEKATAN CONTEXTUAL TEACHING AND LEARNING (CTL) UNTUK MENINGKATKAN KEMAMPUAN BERPIKIR KRITIS DAN RASA INGIN TAHU MAHASISWA PADA MATA KULIAH PENDIDIKAN PANCASILA
}

\author{
Oleh: \\ Triyani ${ }^{(1}$ triyani@fkip.upr.ac.id $)$ \\ Universitas Palangka Raya
}

\begin{abstract}
Abstrak
Penelitian ini bertujuan untuk mengembangkan dan menerapkan pendekatan Contextual Teaching and Learning (CTL) pada mata kuliah pendidikan Pancasila dengan tujuan untuk memperkokoh sikap, pengetahuan, dan keterampilan mahasiswa mengenai pendidikan Pancasila. Luaran penelitian yang dihasilkan adalah publikasi hasil penelitian pada jurnal ilmiah. Instrumen penelitian yang digunakan dalam penelitian ini adalah angket rasa ingin tahu dan soal uraian untuk uji kemampuan berpikir kritis mahasiswa. Subjek uji coba dalam penelitian ini adalah mahasiswa semester tiga (3) yang berjumlah 55 mahasiswa. Analisis data keefektivan berdasarkan hasil tes dilakukan dengan cara menentukan persentase ketuntasan belajar peserta didik dan menentukan gain score $\langle\mathrm{g}\rangle$ pada kelas yang dijadikan subjek penelitian. Berdasarkan pencapaian ketuntasan pembelajaran secara klasikal mencapai $83.64 \%$ dengan jumlah mahasiswa 46 dari 55 mahasiswa. Gain score $<g>$ sebesar 0.61 atau berada pada kategori "sedang". Berdasarkan hasil tes kemampuan berpikir kritis mahasiswa menunjukkan bahwa pendekatan CTL efektiv untuk meningkatkan kemampuan berpikir kritis mahasiswa. Ketercapaian rasa ingin tahu mahasiswa berdasarkan hasil angket pada kategori "sangat tinggi" yakni dengan persentase mencapai $72.73 \%$ atau sebanyak 40 mahasiswa dari 55 mahasiswa. Selain itu gain score $\langle g\rangle$ sebesar 0.61 atau berada pada kategori "sedang". Berdasarkan angket rasa ingin tahu menunjukkan bahwa pendekatan CTL efektif untuk mengembangkan rasa ingin tahu mahasiswa.
\end{abstract}

Kata kunci: keefektifan, pembelajaran kontekstual, berpikir kritis, rasa ingin tahu

\begin{abstract}
This study aims to develop and apply the Contextual Teaching and Learning (CTL) approach to the Pancasila (civic) education course with the aim of strengthening the attitudes, knowledge, and skills of students regarding Pancasila education. The research output produced is the publication of research results in scientific journals. The research instruments used in this study were a curiosity questionnaire and a description of the questions to test the students' critical thinking skills. The subjects of the trial in this study were 55 sophomore students in the third semester. The effectiveness of the data analysis based on the results of the test was done by determining the percentage of students' mastery learning and determining the gain score $\langle\mathrm{g}\rangle$ in the class used as the research subject. Based on the achievement of the mastery learning, the classical learning reached $83.64 \%$ with the number of students 46 out of 55 students. Gain score $<\mathrm{g}>$ is 0.61 or is in the "moderate" category. Based on the results of tests of students" critical thinking skills, the CTL approach was effective to improve students' critical thinking skills. The achievement of students' curiosity based on the results of the questionnaire is in the "very high" category, by the percentage reaching $72.73 \%$ or as many as 40 students from 55 students. In addition, the gain score $<\mathrm{g}>$ is 0.61 or is in the "moderate" category. Based on the curiosity questionnaire, it showed that the CTL approach is effective for developing student's curiosity.
\end{abstract}

Keywords: CTL, critical thinking, curiosity. 


\section{PENDAHULUAN}

Ilmu pengetahuan yang semakin berkembang pesat menuntut sumber daya manusia Indonesia untuk kompetitif terutama dalam bersaing dengan negara lain dalam berbagai bidang kehidupan. Peningkatan kualitas sumber daya manusia menjadi tantangan tersendiri bagi setiap negara. SDM yang unggul dan berkualitas merupakan produk pendidikan yang berkualitas. Berdasarkan laporan dari salah satu lembaga internasional tingkat daya saing sumber daya manusia Indonesia kurang baik. Menurut Human Development Report tahun 2016 versi UNDP peringkat HDI (Human Development Index) atau kualitas sumber daya manusia Indonesia berada di urutan 113 dari 188 negara (UNDP, 2018).

Salah satu terobosan yang dilakukan oleh pemerintah untuk mengembangkan sumber daya manusia yakni melalui jalur pendidikan. Pendidikan nasional di Indonesia bertujuan untuk mengembangkan kemampuan dan membentuk watak serta peradaban bangsa yang bermartabat dalam rangka mencerdaskan kehidupan bangsa. Pendidikan nasional juga memiliki tujuan untuk mengembangkan potensi mahasiswa agar menjadi manusia yang beriman dan bertakwa kepada Tuhan Yang Maha Esa, berakhlak mulia, sehat, berilmu, cukup, kreatif, mandiri, dan menjadi warga negara yang demokratis serta bertanggung jawab.

Proses pembelajaran pendidikan Pancasila seharusnya berorientasi pada pengembangan kemampuan berpikir kritis terutama dalam memecahkan permasalahan dalam kehidupan sehari-hari serta meningkatkan rasa ingin tahu mahasiswa, akan tetapi dalam tataran praktik mahasiswa belum terbiasa berpikir kritis, analisis, dan argumentatif serta kurang terbiasa dengan diskusi interaktif dalam proses pembelajaran. Untuk mengatasi permasalahan tersebut diperlukan suatu model pembelajaran yang mampu memberikan solusi atas permasalahan tersebut. Salah satu model pembelajaran yang dapat memberikan kontribusi dalam pengembangan kemampuan berpikir kritis yakni pendekatan Contextual Teaching and Learning (CTL). Pendekatan CTL merupakan suatu proses pembelajaran yang melibatkan mahasiswa dalam aktivitas penting yang membantu mahasiswa mengaitkan pelajaran akademis dengan kehidupan nyata atau praktik di lapangan (Johnson, 2002).

Dalam hal ini konsep belajar yang mengaitkan antara materi yang diajarkan dengan situasi dunia nyata mampu mendorong mahasiswa membuat hubungan antara pengetahuan yang dimilikinya dengan 
penerapan kehidupan sehari-hari. Mahasiswa yang mampu mengaitkan materi pelajaran dengan konteks kehidupan nyata, semakin banyak makna yang akan mereka dapatkan dari pelajaran tersebut. Pembelajaran $C T L$ menerapkan berbagai masalah kontekstual sebagai titik awal, sehingga mahasiswa belajar dengan menggunakan kemampuannya untuk memecahkan berbagai masalah.

Variasi dalam pembelajaran di perkuliahan diharapkan dapat mengembangkan kemampuan dan potensi mahasiswa secara maksimal. Syarat keberhasilan dalam proses belajar mengajar harus didukung oleh banyak faktor, salah satunya adalah faktor dari dalam individu tersebut. Faktor dari dalam individu tersebut, misalnya motivasi, rasa ingin tahu (curiosity), kemampuan berpikir kritis, minat, kecerdasan dan sebagainya. Menurut Zuss, rasa ingin tahu penting dikembangkan karena berperan sebagai pendorong yang terlibat dalam membantu membuat hubungan antara ide-ide, persepsi, konsep, dan representasi. Hal tersebut memberikan asumsi, jika rasa ingin tahu mahasiswa tinggi maka tujuan pembelajaran atau kompetensi pembelajaran yang telah ditetapkan lebih mudah tercapai (Zuss, 2008). Rowson, menyatakan bahwa curiosity merupakan hal penting untuk inovasi, pertama kaitannya dengan kreativitas dan berpikir divergen, dan kedua peranannya sebagai motivator intrinsik untuk mempertahankan minat (Rowson, 2012).

Pembelajaran pendidikan Pancasila seharusnya berorientasi pada proses mengontruksi pengetahuan. Mahasiswa merupakan subjek yang memiliki kemampuan untuk mencari, mengolah, mengkonstruksi, dan menggunakan pengetahuan. Oleh karena itu, dosen dituntut untuk memahami dan mampu menerapkan berbagai pendekatan pembelajaran yang sesuai dengan kekhasan mahasiswa sehingga mampu memfasilitasi aktivitas mahasiswa dalam belajar. Alternatif pendekatan pembelajaran yang lebih menitikberatkan pada aktivitas mahasiswa dan mampu membangun rasa ingin tahu mahasiswa serta mengembangkan kemampuan berpikir kritis adalah dengan menerapkan Contextual Teaching and Learning (CTL). Untuk menciptakan proses pembelajaran yang berorientasi pada potensi mahasiswa, sudah selayaknya dosen menekankan proses keterlibatan mahasiswa secara penuh dalam mempelajari sebuah materi yang dipelajari dan menghubungkannya dengan kehidupan nyata. Hal ini sangat penting, selain bermakna secara fungsional bagi mahasiswa, 
materi yang dipelajarinya akan tertanam erat dalam memori mahasiswa sehingga tidak akan mudah dilupakan.

Pendekatan CTL merupakan suatu proses pembelajaran yang melibatkan mahasiswa dalam aktivitas penting yang membantu mereka mengaitkan pelajaran akademis dengan konteks kehidupan nyata yang mereka hadapi. Dalam hal ini konsep belajar yang mengaitkan antara materi yang diajarkan dengan situasi dunia nyata mahasiswa mampu mendorong mahasiswa membuat hubungan antara pengetahuan yang dimilikinya dengan penerapan kehidupan sehari-hari. Konteks memberikan makna pada isi, seperti yang diungkapkan oleh Johnson, bahwa semakin banyak keterkaitan yang ditemukan mahasiswa dalam konteks yang lebih luas, semakin bermaknalah isinya bagi mahasiswa. Mahasiswa yang mampu mengaitkan materi pelajaran dengan konteks kehidupan nyata, semakin banyak makna yang akan mereka dapatkan dari pelajaran tersebut. Pembelajaran CTL menerapkan berbagai masalah kontekstual sebagai titik awal, sehingga mahasiswa belajar dengan menggunakan kemampuannya untuk memecahkan berbagai masalah terutama berkaitan dengan masalah politik dewasa ini (Johnson, 2002).

\section{METODE}

Rancangan (design) penelitian yang digunakan dalam penelitian ini adalah implementasi pendekatan pembelajaran Contextual Teaching and Learning (CTL). Penelitian ini menggunakan pendekatan kuantitatif dengan jenis penelitian eksperimen semu (quasi experiment). Subyek penelitian mahasiswa semester III Program Studi PPKn, Jurusan PIPS, FKIP, UPR yang berjumlah 55 mahasiswa dalam mata kuliah Pendidikan Pancasila. Penelitian ini terdiri dari dua variable yakni variable independent dan dependent. Variabel dependent yakni rasa ingin tahu dan berpikir kritis, sementara itu variable independent yakni pendekatan pembelajaran Contextual Teaching and Learning (CTL). Teknik pengumpulan data terdiri dari pemberian angket dan lembar tes. Instrumen pengumpulan data terdiri dari angket dan lembar tes.

Rancangan penelitian ini dilakukan dalam mata kuliah pendidikan Pancasila dan dilaksanakan di tengah semester setelah dilakukan ujian tengah semester (UTS). Pertemuan setelah UTS dengan dengan menerapkan pendekatan Contextual Teaching and Learning (CTL) dalam mata kuliah pendidikan Pancasila. Analisis data dari angket rasa ingin tahu dan lembar tes untuk mengukur kemampuan berpikir kritis 
menggunakan uji t-test dan teknik score $\langle\mathrm{g}\rangle$ (Hake, 1999). Nilai $\langle\mathrm{g}\rangle$ dapat normalized gain score atau normalisasi gain dihitung dengan rumus sebagai berikut.

\section{Uji Gain-Score}

$$
<g>=\frac{\% \text { postscore }-\% \text { prescore }}{100-\% \text { prescore }}
$$

\section{Keterangan:}

$$
\begin{aligned}
& \langle\mathrm{g}> \\
& \begin{array}{l}
\text { \%postscore } \\
\text { \%prescore : prosentase nilai pre-tes }
\end{array}
\end{aligned}
$$

Kriteria indeks $\langle g\rangle$ dapat dilihat pada Tabel 1.

Tabel 1. Kriteria Indeks Gain Rasa Ingin Tahu

\begin{tabular}{|c|c|}
\hline Indeks $<\mathrm{g}>$ & Kriteria \\
\hline$(<\mathrm{g}>)>0.70$ & Tinggi \\
\hline $0.30<(<\mathrm{g}>)<0.70$ & Sedang \\
\hline$(<\mathrm{g}>) \leq 0.30$ & Rendah \\
\hline
\end{tabular}

Disisi lain untuk melihat keefektifan dari pendekatan CTL terhadap kemampuan berpikir kritis dan rasa ingin tahu digunakan presentase ketercapaian pada aspek rasa ingin tahu maupun kemampuan berpikir kritis. Keefektivan pendekatan $C T L$ dapat dilihat dari $75 \%$ mahasiswa mencapai batas minimal nilai yang telah ditentukan oleh dosen mata kuliah yang bersangkutan. Batas minimum nilai mahasiswa pada mata kuliah pendidikan
Pancasila yakni 75. Sedangkan, keefektivan rasa ingin tahu dapat dilihat dari ketercapaian rasa ingin tahu mahasiswa sebanyak $75 \%$ dari total mahasiswa rasa ingin tahunya berada pada kategori "sedang" Untuk mengetahui presentase ketercapaian kemampuan berpikir krtitis dan rasa ingin tahu mahasiswa menggunakan perhitungan sebagai berikut.

$$
\% \text { Efektif }=\frac{\text { Jumlah peserta didik yang memperoleh skor di atas } \mathrm{KKm}}{\text { Jumlah seluruh peserta didik }} \times 100 \%
$$

\section{HASIL DAN PEMBAHASAN}

Dalam penelitian ini terdiri dari dua variable yakni variable independen dan variable dependen. Variabel dependen dalam penelitian ini adalah rasa ingin tahu dan 
kemampuan berpikir kritis, sedangkan variable independen adalah pendekatan pembelajaran Contextual Teaching and Learning $(C T L)$.

\section{a. Kemampuan Berpikir Kritis}

Kemampuan berpikir kritis dalam penelitian ini diukur dengan menggunakan instrumen lembar tes berupa soal uraian berjumlah 5 butir soal. Sebelum dilakukan proses pembelajaran dengan menerapkan pendekatan Contextual Teaching and Learning (CTL), terlebih dahulu dilakukan kegiatan pre-test untuk mengetahui kemampuan awal mahasiswa terkait kemampuan berpikir krtitis. Subjek pre-test yakni mahasiswa semester 3 (tiga) yang terdiri dari 55 mahasiswa. Berikut hasil tes kemapuan berpikir kritis mahasiswa prodi PPKn untuk mata kuliah pendidikan Pancasila.

Tabel 2. Data Kemampuan Berpikir Kritis Mahasiswa PPKn Semester Tiga

\begin{tabular}{|c|c|c|c|c|}
\hline Perlakuan & $\begin{array}{c}\text { Jumlah } \\
\text { Mahasiswa }\end{array}$ & $\begin{array}{c}\text { Nilai } \\
\text { Tertinggi }\end{array}$ & $\begin{array}{c}\text { Nilai } \\
\text { Terendah }\end{array}$ & $\begin{array}{c}\text { Rata- } \\
\text { rata }\end{array}$ \\
\hline \multicolumn{5}{|c|}{ Kelas Eksperimen } \\
\hline Pre-Test & 55 & 76 & 44 & 63.64 \\
\hline Post-Test & 55 & 96 & 68 & 85.73 \\
\hline
\end{tabular}

Berdasarkan hasil pre-test nilai terendah adalah 44 dan nilai tertinggi sebesar 76 dan nilai rata-rata sebesar 63.64. Sedangkan hasil post test menunjukkan bahwa nilai terendah sebesar 68 , nilai tertinggi sebesar 96 dan dengan nilai ratarata 85.73. Berdasarkan hasil pre-test dan post-test yang telah dilakukan dapat diketahui ketuntasan pembelajaran pendidikan Pancasila adalah sebagai berikut.

Tabel 3. Persentase Ketuntasan Pembelajaran PPKn Pre-Test dan Post-Test

\begin{tabular}{|c|c|c|c|c|}
\hline No. & Kriteria & Kategori & Frekuensi & Persentase \\
\hline \multicolumn{5}{|c|}{ Pre-Test } \\
\hline 1. & $<75$ & Belum Tuntas & 48 & $87.27 \%$ \\
\hline 2. & $\geq 75$ & Tuntas & 7 & $12.73 \%$ \\
\hline \multicolumn{5}{|c|}{ Post-Test } \\
\hline 3. & $<75$ & Belum Tuntas & 9 & $16.36 \%$ \\
\hline 4. & $\geq 75$ & Tuntas & 46 & $83.64 \%$ \\
\hline
\end{tabular}

Hasil pre-test menunjukkan bahwa 48 mahasiswa $(87.27 \%)$ mendapatkan nilai di bawah standar yang ditentukan oleh dosen, yakni 75. Sementara mahasiswa yang masuk ke dalam kategori tuntas sebanyak 7 mahasiswa dengan persentase $12.73 \%$. Sedangkan untuk post-test menunjukkan bahwa 9 mahasiswa (16.36\%) mendapatkan nilai di bawah yang ditentukan oleh dosen, yakni 75. Sementara mahasiswa yang masuk 
ke dalam kategori tuntas sebanyak 46 dengan persentase $83.64 \%$. Dilihat dari gain score $\langle g\rangle$ menunjukkan angka 0.61 atau dalam kategori "Sedang”. Berikut tabel mengenai analisis gain score kemampuan berpikir kritis mahasiswa PPKn semester 3 (tiga) untuk mata kuliah pendidikan Pancasila.

Tabel 4. Analisis Gain Score

\begin{tabular}{|l|r|r|}
\hline & Pre-Test & $\begin{array}{c}\text { Post- } \\
\text { Test }\end{array}$ \\
\hline Jumlah Skor & 3500 & 4715 \\
\hline Jumlah Skor Maksimal & 5500 & 5500 \\
\hline Presentase Skor Pre \& Post & 63.64 & 85.73 \\
\hline Presentase Ketuntasan & 3.13 & 71.88 \\
\hline Rata-Rata Nilai (Mean) & 63.64 & 85.73 \\
\hline Gain Skor Kelas Eksperimen & \multicolumn{3}{|c|}{0.61} \\
\hline
\end{tabular}

Dari data di atas, dapat disimpulkan bahwa terjadi kenaikan kemampuan berpikir krtitis mahasiswa dengan melihat jumlah dan persentase yang tuntas dalam pembelajaran PPKn. Hasil post-test menunjukkan bahwa terdapat 9 mahasiswa (16.36\%) mendapatkan nilai di bawah standar yang ditentukan oleh dosen, yakni 75. Sementara mahasiswa yang masuk ke dalam kategori tuntas sebanyak 46 orang dengan persentase $83.64 \%$. Sementara hasil pre-test menunjukkan bahwa 48 mahasiswa $(87.27 \%)$ mendapatkan nilai di bawah standar yang ditentukan oleh dosen, yakni 75. Sementara mahasiswa yang masuk ke dalam kategori tuntas sebanyak 7 mahasiswa dengan persentase $12.73 \%$.

\section{b. Rasa Ingin Tahu}

Data rasa ingin tahu dalam penelitian ini menghasilkan dua macam data, yakni data skor pre-test dan skor post-test. Sebelum dilakukan pembelajaran, terlebih dahulu dilakukan kegiatan pre-test dengan tujuan untuk mengetahui kondisi awal rasa ingin tahu mahasiswa sebelum dilakukan pembelajaran dengan menggunakan pendekatan Contextual Teaching and Learning (CTL). Untuk selanjutnya diadakan post-test di tengah semester mengetahui dan mengukur rasa ingin tahu mahasiswa setelah dilakukan pembelajaran menggunakan pendekatan Contextual Teaching and Learning (CTL). Subjek pada pre-test dan post-test yakni mahasiswa semester tiga prodi PPKn yang berjumlah 55 mahasiswa. Berikut ini hasil dari pengisian angket rasa ingin tahu mahasiswa baik pada pre-test maupun post-test. 
Tabel 5. Data Hasil Keefektivan Pendekatan CTL Berdasarkan Angket Rasa Ingin Tahu Mahasiswa Prodi PPKn

\begin{tabular}{|c|c|c|}
\hline Kategori & Frekuensi & Persentase \\
\hline \multicolumn{3}{|c|}{ Pre-Test } \\
\hline Sangat tinggi & 2 & $3.64 \%$ \\
\hline Tinggi & 4 & $7.27 \%$ \\
\hline Sedang & 41 & $74.55 \%$ \\
\hline Rendah & 8 & $14.55 \%$ \\
\hline Sangat rendah & 0 & $0 \%$ \\
\hline \multicolumn{3}{|c|}{ Post-Test } \\
\hline Sangat tinggi & 40 & $72.73 \%$ \\
\hline Tinggi & 13 & $23.64 \%$ \\
\hline Sedang & 2 & $3.64 \%$ \\
\hline Rendah & 0 & $0 \%$ \\
\hline Sangat rendah & 0 & $0 \%$ \\
\hline
\end{tabular}

Berdasarkan data pre-test rasa ingin tahu mahasiswa sebanyak 41 mahasiswa atau $74.55 \%$ berada pada posisi "sedang". Sedangkan 2 mahasiswa (3.64\%) berada pada kategori "sangat tinggi", 4 mahasiswa (7.27\%) berada pada kategori "tinggi", dan 8 mahasiswa (14.55\%) berada pada kategori "rendah". Berdasarkan kondisi tersebut, untuk selanjutnya diadakan sebuah perlakuan yakni menerapkan pendekatan CTL pada proses pembelajaran pendidikan Pancasila. Berdasarkan hasil post-test, rasa ingin tahu mahasiswa rata-rata berada pada kategori "tinggi" dengan jumlah mahasiswa sebanyak 13 atau $23.64 \%$. Sedangkan mahasiswa yang mencapai kategori "sangat tinggi" sebanyak 40 orang atau $72.73 \%, 2$ mahasiswa $(3.64 \%)$ mencapai kategori "sedang”, serta tidak ada mahasiswa yang berada pada kategori "rendah" maupun "sangat rendah".

Dilihat dari gain score $\langle g\rangle$ menunjukkan angka 0.61 atau dalam kategori "sedang". Berikut tabel mengenai analisis gain score rasa ingin tahu mahasiswa.

Tabel 6. Analisis Gain Score Rasa Ingin Tahu Mahasiswa Prodi PPKn

\begin{tabular}{|l|l|l|}
\hline & $\begin{array}{l}\text { Pre- } \\
\text { Test }\end{array}$ & $\begin{array}{l}\text { Post- } \\
\text { Test }\end{array}$ \\
\hline Jumlah Skor & 2495 & 3497 \\
\hline Jumlah Skor Maksimal & 4125 & 4125 \\
\hline Presentase Skor Pre \& Post & 60.48 & 84.78 \\
\hline
\end{tabular}




\begin{tabular}{|l|l|l|} 
Presentase Ketuntasan & & \\
\hline Rata-Rata Skor (Mean) & & \\
\hline Gain Skor Kelas Eksperimen & 0.61 & \\
\hline
\end{tabular}


Dari seluruh data yang telah diuraikan, dapat disimpulkan bahwa terjadi perubahan rasa ingin tahu mahasiswa pada saat pre-test dan post-test. Pada saat pretest rasa ingin tahu mahasiswa berada pada kategori "sedang" dengan persentase $74.55 \%$ dari total seluruh mahasiswa yakni sebanyak 55 orang. Dan pada saat post-test rasa ingin tahu mahasiswa berada pada kategori "sangat tinggi" dengan persentase $72.73 \%$ dari total seluruh mahasiswa yakni sebanyak 55 orang. Dari data tersebut jelas terdapat perubahan rasa ingin tahu mahasiswa antara pre-test dan post-test.

Berdasarkan hasil analisis data mengenai keefektivan penggunaan pendekatan $C T L$ pada proses pembelajaran pendidikan Pancasila terhadap kemampuan berpikir kritis dan rasa ingin tahu mahasiswa dapat disimpulkan bahwa penggunaan pendekatan $C T L$ efektiv untuk meningkatkan kemampuan berpikir kritis dan rasa ingin tahu mahasiswa. Dengan demikian, diyakini bahwa pendekatan $C T L$ memberikan efek yang signifikan untuk meningkatkan kemampuan berpikir kritis dan rasa ingin tahu mahasiswa, sehingga dapat dijadikan alternatif untuk mendukung proses pembelajaran khususnya pada mata kuliah pendidikan Pancasila.

Shamsid-Deen \& Bettye, menjelaskan bahwa CTL merupakan " $a$ conception of teaching and leraning that helps teachers relate subject matter content to real world situations". Pendekatan kontekstual menyajikan suatu konsep pembelajaran yang dapat membantu dosen mengaitkan materi pelajaran dengan situasi dunia nyata mahasiswa. Secara garis besar pendekatan ini mendorong mahasiswa untuk menghubungkan pengetahuan yang telah mereka miliki dengan pengetahuan yang baru mereka pelajari dengan tujuan untuk dipergunakan dalam kehidupan sehari-hari dalam keluarga atau masyarakat (Shamsid \& Bettye, 2006).

Pendekatan CTL dapat meningkatkan kemampuan berpikir kritis mahasiswa. Kemampuan berpikir kritis dalam penelitian ini merupakan kemampuan mahasiswa dalam menganalisis, mensistesis, memecahkan masalah, menyimpulkan dan mengevaluasi permasalahan. Dalam proses pembelajaran kemampuan berpikir kritis perlu diajarkan pada mahasiswa. Kemampuan berpikir kritis diperlukan untuk menyikapi suatu permasalahan dengan baik (Shamsid \& Bettye, 2006). Kemampuan berpikir kritis merupakan kemampuan yang sangat penting bagi setiap mahasiswa yang dapat digunakan dalam memecahkan masalah dalam berpikir serius, aktif, teliti dalam menganalisis semua informasi yang mereka terima dengan menyertakan alasan.

yang rasional sehingga setiap tindakan yang akan dilakukan adalah benar. 
Selain berpikir kritis, pendekatan $C T L$ juga mampu meningkatkan rasa ingin tahu mahasiswa, mengeksplorasi rasa ingin tahu untuk penyelidikan dan pengetahuan. Rasa ingin tahu adalah keinginan untuk belajar dan mempelajari sesuatu agar mendapat informasi ataupun pengetahuan baru. Belajar bukan sekedar menerima dan mengetahui, namun mengarah kepada eksplorasi guna memberi makna atas apa yang dipelajari. Curiosity is a desire to learn, investigate, or know. It is an interest leading to exploration or inquiry. Maksudnya rasa ingin tahu adalah keinginan untuk belajar, menyelidiki atau mencari tahu. Rasa ingin tahu juga merupakan ketertarikan yang mengarah pada eksplorasi atau penyelidikan (Schmitt \& Lahroodi,2008).

\section{KESIMPULAN}

Berdasarkan hasil penelitian yang telah dilakukan dapat disimpukan bahwa pendekatan Contextual Teaching and Learning (CTL), dapat meningkatkan kemampuan berpikir kritis dan rasa ingin tahu mahasiswa prodi PPKn semester tiga (3) khususnya pada mata kuliah Pendidikan Pancasila.

a. Berdasarkan pencapaian ketuntasan pembelajaran secara klasikal mencapai $83.64 \%$ dengan jumlah mahasiswa 46 dari 55 mahasiswa. Gain score $\langle g\rangle$ sebesar 0.61 atau berada pada kategori "sedang". Berdasarkan hasil tes kemampuan berpikir kritis mahasiswa menunjukkan bahwa pendekatan CTL efektif untuk meningkatkan kemampuan berpikir kritis mahasiswa.

b. Ketercapaian rasa ingin tahu mahasiswa berdasarkan hasil angket pada kategori "sangat tinggi" yakni dengan persentase mencapai $72.73 \%$ atau sebanyak 40 mahasiswa dari 55 mahasiswa. Selain itu gain score $\langle g\rangle$ sebesar 0.61 atau berada pada kategori "sedang". Berdasarkan angket rasa ingin tahu menunjukkan bahwa pendekatan $C T L$ efektif untuk mengembangkan rasa ingin tahu mahasiswa.

\section{DAFTAR PUSTAKA}

Hake, R. R, 1999), Analyzing Change/ Gain Score. American Educational Research Methodology, diakses tanggal 10 Januari 2017, dari http://lists.asu.edu/cgibin/wa?A2=i nd9903\&L=aera-d \&P=R6855.

Johnson, E. B, 2002, Contextual Teaching And Learning, Tousand Oaks, California, Corwin Press.

Rowson, J, 2012, The Power Of Curiosity, London, RSA Sosial Brain Centre.

Shamsid-Deen, I \& Bettye P.S, 2006, Contextual teaching and learning practices in the family and consumer sciences curriculum. Journal of Family and Consumer Sciences Education, 24 (1), 14-27.

Schmitt, F. F. \& Lahroodi, R, 2008, The epistemic value of curiosity, Educational Theory, 58, (2), 125148. 
UNDP, 2016, Human Development Report 2016.

http://hdr.undp.org/sites/default/fi les/2016_human_development_re port.pdf, diakses tanggal 10 Mei 2018.

Zuss, M, 2008, The Practice Of Theoretical Curiosity, New York, Springer 